\title{
Penetapan Standar Warna Daun Sebagai Upaya Identifikasi Status Hara (N) Tanaman Jagung (Zea mays L.) pada Tanah Regosol
}

\author{
DOI 10.18196/pt.2015.034.8-15
}

\author{
Wisnu Sapto Nugroho \\ PT. Astra Agro Lestari, Kawasan Industri Pulogudang,
}

Blok OR. 1-2, Pulo Ayang Raya, Rw. 9, Jatinegara, Cakung, Kota Jakarta Timur, Daerah Khusus Ibukota, Jakarta 13920, Indonesia, e-mail:wiesnoe83@yahoo.co.id

\begin{abstract}
ABSTRAK
Penelitian ini bertujuan untuk mendapatkan standar warna hijau daun pada masa pertumbuhan sebagai metode untuk mengidentifikasi kecukupan hara Nitrogen pada tanaman Jagung. Penelitian dilaksanakan di lahan percobaan Universitas Muhammadiyah Yogyakarta. Penelitian disusun menggunakan Rancangan Acak Lengkap faktor tunggal terdiri dari 7 perlakuan yaitu (1) 125 kg N/ha, (2) 150 kg N/ha, (3) 175 kg N/ha, (4) 200 kg N/ha, (5) 225 kg N/ha, (6) $250 \mathrm{~kg}$ N/ha dan (7) $275 \mathrm{~kg}$ N/ha. Hasil penelitian menunjukkan Skala warna daun yang tepat untuk mengidentifikasi status hara N pada hasil tanaman jagung yaitu antara skala 5GY 5/8 - 5GY 6/8 pada dosis antara 250 kg N/ha sampai 275 kg N/ha. Pemberian pupuk nitrogen dengan dosis 250 kg N/ha memberikan pengaruh pertumbuhan paling tinggi pada parameter tinggi tanaman. Pemberian pupuk nitrogen dengan dosis $275 \mathrm{~kg} N /$ ha memberikan hasil paling tinggi pada komponen berat biji per tongkol dan berat 100 butir biji pada kadar air 14\%.

Kata kunci: Jagung, Status Nitrogen, Standar warna daun
\end{abstract}

\section{ABSTRACT}

A study aims to determine a standard of green color on corn leaves as marker of nitrogen adequacy. A study was conducted in the field of Universitas Muhammadiyah Yogyakarta. The experiment was arranged in a completely randomized design (CRD, which consisted of 7 treatments: $125 \mathrm{~kg}$ N/h (N1), $150 \mathrm{~kg} \mathrm{~N} / \mathrm{h}$ (N2), $175 \mathrm{~kg} \mathrm{N/h}$ (N3), $200 \mathrm{~kg}$ N/h (N4), $225 \mathrm{~kg} \mathrm{N/h}$ (N5), $250 \mathrm{~kg}$ N/h (N6), and $275 \mathrm{~kg}$ N/h (N7). The result showed that the scale between $5 G Y 5 / 8$ and 5GY 6/8 was the best Leaf color scale to identify Nitrogen condition on corn yield at range of $250 \mathrm{~kg} N / \mathrm{h}$ and $275 \mathrm{~kg} / \mathrm{h}$. The dose of 250 $\mathrm{kg} \mathrm{N/h} \mathrm{resulted} \mathrm{the} \mathrm{highest} \mathrm{plant} \mathrm{height} \mathrm{of} \mathrm{corn.} \mathrm{The} \mathrm{dose} \mathrm{of} 275 \mathrm{~kg}$ N/h resulted the highest seed weight per ear and grain weight of 100 seeds at $14 \%$ moisture content.

Keywords: Corn, Nitrogen content, Leaf color standard

\section{PENDAHULUAN}

Jagung (Zea mays L.) merupakan komoditas penting bagi bangsa Indonesia karena merupakan komoditas utama penghasil karbohidrat setelah beras. Selain itu, jagung juga digunakan sebagai pakan ternak dan bahan baku industri lainnya. Dalam beberapa tahun terakhir peningkatan kebutuhan jagung tidak sejalan dengan laju peningkatan produksi di dalam negeri sehingga diperlukan impor jagung yang makin besar. Biji jagung kaya akan karbohidrat, sebagian besar karbohidrat tersebut berada pada endospermium. Kandungan karbohidrat dapat mencapai $80 \%$ dari seluruh bahan kering biji (Irmayani, 2011).
Produksi jagung di Indonesia masih rendah karena belum memenuhi kebutuhan masyarakat. Hal ini dikarenakan banyak faktor, salah satunya adalah permasalahan budidaya. Salah satu masalah budidaya yang muncul adalah rendahnya efisiensi penggunaan pupuk Nitrogen. Pupuk N berperan penting dalam peningkatan produksi jagung. Unsur hara $\mathrm{N}$ menjadi unsur hara utama penyusun Klorofil, yang memiliki peranan penting dalam proses fotosintesis pada tanaman. Tanaman yang kekurangan unsur hara $\mathrm{N}$, daunnya akan menguning sehingga proses fotosintetis tidak maksimal. Selain itu unsur hara $\mathrm{N}$ juga berperan dalam penyusun asam-asam 
amino, protein serta bahan penyusun komponen inti sel. Pemberian pupuk $\mathrm{N}$ yang berlebihan pada tanaman jagung dapat meningkatkan kerusakan akibat serangan hama dan penyakit terutama pada musim hujan, memperpanjang umur, dan tanaman lebih mudah rebah akibat batang dari daun yang berlebihan dari ukuran normal, sedangkan akar tidak mampu menahan. Penggunaan pupuk yang berlebihan, selain akan memperbesar biaya produksi juga akan merusak lingkungan akibat adanya emisi gas $\mathrm{N}_{2} \mathrm{O}$ pada proses amonifikasi, nitrifikasi, dan denitrifikasi (Wahid, 2003).

Salah satu alternatif untuk meningkatkan efisiensi pupuk $\mathrm{N}$ adalah dengan mempertahankan kondisi tanaman dalam keadaan cukup hara $\mathrm{N}$ namun tidak berlebihan.. Pemberian pupuk $\mathrm{N}$ ke dalam tanah harus memperhatikan status hara serta kebutuhan tanaman untuk mencapai hasil yang optimal (Balai Penelitian Tanah, 2008). Suwardi dan Efendi (2009) menyatakan bahwa tanaman jagung dalam pertumbuhan fase awal sampai masak fisiologis membutuhkan nitrogen sekitar 120-180 kg/ha sedangkan N yang terangkut ke tanaman jagung hingga panen sekitar 129-165 kg/ha dengan tingkat hasil 9,5 ton/ha.

Penentuan kondisi tanaman kritis terhadap $\mathrm{N}$ dilakukan dengan menggunakan SPAD (Soil Plant Analysis Development) yang dapat mendeteksi kandungan hara tanaman. Harga alat SPAD cukup mahal (sekitar US\$1500/unit) sehingga sulit dijangkau oleh petani. Metode ini kemudian dimodifikasi dengan suatu alat berupa bagan warna daun (BWD) atau leaf color chart (LCC). Prinsip kerja alat ini adalah memanfaatkan warna hijau daun yang terbentuk oleh zat warna hijau pada klorofil. Klorofil tersusun atas rantai Nitrogen. Penggunaan BWD memberikan gambaran optimalisasi penggunaan N. BWD merupakan alat peraga untuk menduga status $\mathrm{N}$ daun, sangat sederhana, tidak bersifat merusak, murah dan mudah digunakan, ramah lingkungan dan dapat dimiliki oleh petani karena harganya terjangkau. (Wahid, 2003).

Penelitian ini bertujuan untuk mendapatkan standar warna hijau daun yang tepat terhadap pertumbuhan dan hasil tanaman jagung sebagai identifikasi status kecukupan hara N.

\section{BAHAN DAN METODE}

Penelitian ini dilaksanakan di Kebun Percobaan dan Laboratorium Penelitian Fakultas Pertanian Universitas Muhammadiyah Yogyakarta, Tamantirto, Kasihan, Bantul, DIY. Bahan yang digunakan dalam penelitian ini adalah benih jagung hibrida varietas Bisi 2, pupuk kandang kambing 20 ton/ha, pupuk KCl, pupuk SP-36 dan pupuk urea, tanah regosoL. Penentuan warna daun dilakukan dengan menggunakan munshell colour chart.

Penelitian ini disusun dalam Rancangan Acak Lengkap (RAL) factor tunggal dengan 7 perlakuan pemupukan $\mathrm{N}$ dan masing-masing perlakuan terdiri dari 3 ulangan sebagai berikut: 1). $125 \mathrm{~kg} \mathrm{~N} / \mathrm{ha}(\mathrm{N} 1), 2) .150 \mathrm{~kg} \mathrm{~N} / \mathrm{ha}(\mathrm{N} 2), 3)$. $175 \mathrm{~kg} \mathrm{~N} / \mathrm{ha}(\mathrm{N} 3), 4) .200 \mathrm{~kg} \mathrm{~N} / \mathrm{ha}(\mathrm{N} 4), 5) .225$ $\mathrm{kg} \mathrm{N} /$ ha (N5), 6). $250 \mathrm{~kg} \mathrm{~N} /$ ha (N6), dan 7). 275 $\mathrm{kg} \mathrm{N} /$ ha (N7).

Parameter pengamatan yang diamati yaitu tinggi tanaman, jumlah daun, warna hijau daun, luas daun, berat segar tanaman, berat kering tanaman, berat segar tongkol tanpa kelobot, berat kering tongkol tanpa kelobot, berat biji/tongkol dan berat 100 butir biji (pada kadar air 14\%). Data hasil pengamatan ditabulasi dan dianalisis. Analisis menggunakan Sidik Ragam atau Anova (Analysis of variance) pada taraf $\alpha=5 \%$. Apabila ada beda nyata, maka digunakan uji lanjut $\mathrm{Uji}$ Jarak Berganda Duncan (UJGD) pada taraf $\alpha=$ $5 \%$. 


\section{HASIL DAN PEMBAHASAN}

Pertumbuhan Vegetatif

Ketersediaan unsur hara dalam tanah akan mempengaruhi pertumbuhan tanaman dalam hal ini yaitu ketersediaan unsur nitrogen yang dibutuhkan tanaman selama pertumbuhan vegetatif maupun generatif. Parameter selama pertumbuhan vegetatif yang diamati adalah tinggi tanaman, jumlah daun dan luas daun (tabel 1).

Tabel 1. Rerata Tinggi Tanaman, Jumlah Daun dan Luas Daun Sebagai Respon terhadap Pemberian Dosis Nitrogen yang Berbeda

\begin{tabular}{rccc}
\hline Perlakuan & Tinggi Tanaman (cm) & Jumlah Daun (helai) & Luas Daun (cm2) \\
\hline $125 \mathrm{~kg} \mathrm{~N} / \mathrm{ha}$ & $77,33 \mathrm{abc}$ & 12,00 & 4244,3 \\
$150 \mathrm{~kg} \mathrm{~N} / \mathrm{ha}$ & $74,00 \mathrm{bc}$ & 12,33 & 4355,0 \\
$175 \mathrm{~kg} \mathrm{~N} / \mathrm{ha}$ & $81,33 \mathrm{a}$ & 14,33 & 4402,7 \\
$200 \mathrm{~kg} \mathrm{~N} / \mathrm{ha}$ & $73,67 \mathrm{c}$ & 13,33 & 4837,0 \\
$225 \mathrm{~kg} \mathrm{~N} / \mathrm{ha}$ & $80,33 \mathrm{ab}$ & 14,00 & 5276,3 \\
$250 \mathrm{~kg} \mathrm{~N} / \mathrm{ha})$ & $82,33 \mathrm{a}$ & 13,67 & 4718,0 \\
$275 \mathrm{~kg} \mathrm{~N} / \mathrm{ha})$ & $77,17 \mathrm{abc}$ & 14,33 & 4899,7 \\
\hline
\end{tabular}

Keterangan: Angka yang diikuti huruf yang sama dalam satu kolom menunjukkan tidak berbeda nyata berdasarkan DMRT $5 \%$.

Rerata tinggi tanaman pada perlakuan 250 $\mathrm{kg} \mathrm{N} /$ ha dan $175 \mathrm{~kg} \mathrm{~N} /$ ha menunjukkan hasil paling tinggi. Hal ini menunjukkan bahwa ketersediaan unsur hara khususnya nitrogen pada pelakuan 175 dan $250 \mathrm{~kg} \mathrm{~N} /$ ha sudah terpenuhi. Pertumbuhan tinggi tanaman dapat diakibatkan karena ketersediaan unsur hara dan air yang cukup dalam tanah. Terutama unsur nitrogen yang digunakan untuk pertumbuhan batang dan daun. Jika unsur $\mathrm{N}$ tersedia cukup dalam tanah maka proses fotosintesis akan berjalan lancar dan hasil fotosintatnya akan banyak sehingga tinggi tanaman akan dipercepat. Pertumbuhan tinggi tanaman dipengaruhi oleh sinar matahari yang diterima tanaman (Nurhayati, 2003 dalam Djaafar, 2010). Pertumbuhan tinggi batang terjadi di dalam meristem interkalar dari ruas. Ruas memanjang sebagai akibat meningkatnya jumlah sel dan meluasnya sel. Pertumbuhan karena pem- belahan sel terjadi pada dasar ruas bukan pada meristem ujung (Gardner, dkk., 1991).

Hasil sidik ragam menunjukkan pemberian pupuk $\mathrm{N}$ dengan dosis yang berbeda memberikan pengaruh yang sama terhadap parameter pengamatan jumlah daun (Tabel 1). Jumlah daun yaitu berkisar antara 12-14,33 helai. Nitrogen mempunyai peranan yang sangat penting dalam pertumbuhan vegetatif tanaman. Namun penyerapan unsur $\mathrm{N}$ oleh tanaman juga dipengaruhi oleh lingkungan di sekitar tanaman. Peningkatan pertumbuhan tinggi tanaman menyebabkan bertambahnya jumlah daun karena laju pertumbuhan semakin meningkat dengan bertambahnya umur tanaman, namun pada saat tanaman memasuki fase vegetatif maksimal atau masuk fase generatif peningkatan jumlah daun jagung menunjukkan tidak beda nyata. Hal ini disebabkan jumlah daun dalam satu tanaman ditentukan oleh sedikitnya primordia daun yang terbentuk pada tanaman tersebut, sehingga daun suatu tanaman akan berkurang jika perkembangannya tidak didukung oleh lingkungan yang memadai (Utami, 2005). Hal ini juga menunjukkan bahwa jumlah daun yang terbentuk pada tanaman dipengaruhi oleh faktor genetik dari tanaman. Anischan (2013) menyatakan bahwa respons tanaman terhadap $\mathrm{N}$ juga tergantung pada baik buruknya suplai unsur hara yang lainnya. Tanpa pemberian $\mathrm{P}$ dan $\mathrm{K}$ respons hasil terhadap peningkatan $\mathrm{N}$ lebih rendah dibanding bila $\mathrm{P}$ dan K diberikan dalam jumlah yang cukup. Disamping itu, respon terhadap pemberian $\mathrm{P}$ dan $\mathrm{K}$ akan lebih besar bila suplai $\mathrm{N}$ makin banyak.

Berdasakan hasil sidik ragam pada parameter luas daun menunjukkan tidak ada beda nyata. Meskipun tidak berbeda nyata, akan tetapi ada kecenderungan peningkatan luas daun sampai pada pemberian dosis N $225 \mathrm{~kg} /$ ha (Tabel 1). Hal ini menunjukkan adanya pengaruh keterse- 
diaan unsur $\mathrm{N}$ terhadap pembentukan sel daun. Penambahan pupuk $\mathrm{N}$ menyebabkan luas daun semakin besar, sehingga diharapkan akan meningkatkan fotosintetis. Fotosintetis diharapkan akan meningkatkan pertumbuhan dan perkembangan tanaman, karena fotosintat yang dihasilkan lebih besar. Panjang, lebar, dan luas daun umumnya meningkat berangsur-angsur menurut ontogeni samapai ke suatu titik kemudian pada spesies tertentu menurun perlahan-lahan menurut ontogeni, sehingga daun terbesar terletak dekat dengan pusat tanaman. Berat dan luas maksimum daun suatu tanaman tercapai pada awal daur hidupnya, setelah itu meningkatnya berat dan luas daun sama, dengan menurunnya suatu status yang disebut sebagai luas daun kritis (Gardner, dkk., 1991). Maka dari itu, meskipun ada kecenderungan peningkatan luas daun dari tiap dosis pemberian pupuk $\mathrm{N}$, namun di saat tanaman memasuki fase generatif tidak ada beda nyata pada parameter luas daun. Hal ini disebabkan awal daur hidup tanaman sudah terlewati sehingga tidak ada lagi peningkatan yang signifikan pada luas daun.

\section{Pertumbuhan Generatif}

Pengamatan berat segar tanaman dilakukan pada minggu ke delapan setelah tanam dengan cara menimbang seluruh tanaman jagung. Dari hasil sidik ragam menunjukkan bahwa tidak ada beda nyata dari semua perlakuan. Meskipun tidak ada beda nyata, namun ada kecenderungan semakin meningkatnya berat segar tanaman dengan penambahan dosis pupuk N. Peningkatan berat segar tanaman dapat dilihat pada Gambar 1.

Dosis pupuk N $275 \mathrm{~kg} /$ ha menunjukkan hasil paling tinggi. Hal ini terjadi karena kebutuhan $\mathrm{N}$ bagi pertumbuhan tanaman jagung terpenuhi sehingga pertumbuhan tanaman berjalan maksimal. Sementara dosis pupuk N $125 \mathrm{~kg} /$ ha menunjukkan hasil paling rendah. Hal ini karena kebutuhan nitrogen bagi pertumbuhan vegetatif tanaman belum terpenuhi yang ditunjukkan oleh parameter berat segar tanaman. Jumin (1991) dalam Adinata (2004) menyatakan bahwa pemupukan yang tersedia terutama pupuk nitrogen akan mempertinggi pertumbuhan vegetatif tanaman. Tanaman yang kekurangan unsur nitrogen mengalami hambatan dalam pembentukan hijau daun yang sangat berperan dalam fotosintesis, sehingga pembentukan karbohidrat yang berfungsi untuk energi dan pembentukan sel bagi pertumbuhan tanaman menjadi kurang akibatnya tanaman menjadi kuning dan pertumbuhan lambat.

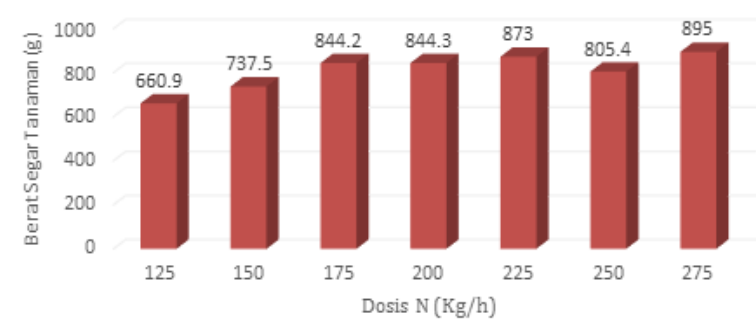

Gambar 1. Pengaruh Pemberian N terhadap Berat Segar Tanaman

Berat kering tanaman diamati setelah tanaman mengalami berat yang konstan setelah dikeringkan dalam oven. Berat kering tanaman merupakan hasil yang menunjukkan optimalisasi serapan unsur hara oleh tanaman selama pertumbuhan dalam bentuk akumulasi fotosintat yang dihasilkan dari proses fotosintesis. Pengaruh pemberian nitrogen terhadap berat kering tanaman dapat dilihat pada gambar 2 .

Perlakuan $275 \mathrm{~kg} \mathrm{~N} /$ ha memberikan hasil paling tinggi terhadap parameter berat kering tanaman. Tanaman yang pertumbuhan vegetatifnya baik akan mempunyai berat segar yang tinggi diikuti oleh kandungan air yang rendah maka 
akan diperoleh berat kering yang tinggi (Adinata, 2004). Dari tabel 2 dapat diketahui bahwa perlakuan antar dosis pupuk $\mathrm{N}$ sebesar $125 \mathrm{~kg} / \mathrm{ha}$, $150 \mathrm{~kg} / \mathrm{ha}, 175 \mathrm{~kg} / \mathrm{ha}, 200 \mathrm{~kg} / \mathrm{ha}, 225 \mathrm{~kg} / \mathrm{ha}$, $250 \mathrm{~kg} / \mathrm{ha}, 275 \mathrm{~kg} / \mathrm{ha}$ tidak memberikan pengaruh nyata terhadap parameter berat kering tanaman. Hal ini terjadi karena ada kemungkinan adanya ketidakseimbangan antara dosis pupuk $\mathrm{N}$ dengan unsur yang lain yaitu $\mathrm{P}$ dan $\mathrm{K}$ sehingga tidak ada perbedaan yang signifikan terhadap pertumbuhan tanaman. Kemungkinan ini didasarkan pada pernyataan Anischan (2013) yang menyatakan bahwa respons tanaman terhadap $\mathrm{N}$ juga tergantung pada baik buruknya suplai unsur hara yang lainnya. Tanpa pemberian $\mathrm{P}$ dan $\mathrm{K}$ respons hasil terhadap peningkatan $\mathrm{N}$ lebih rendah dibanding bila $\mathrm{P}$ dan $\mathrm{K}$ diberikan dalam jumlah yang cukup. Disamping itu, respons terhadap pemberian $\mathrm{P}$ dan $\mathrm{K}$ adalah lebih besar bila suplai $\mathrm{N}$ banyak. Peningkatan pemberian dosis pupuk $\mathrm{N}$ yang tidak diiringi dengan peningkatan dosis $\mathrm{P}$ dan $\mathrm{K}$ diduga menjadi penyebab tidak maksimalnya penyerapan unsur hara karena terjadi ketidakseimbangan antara pupuk N, P dan K.

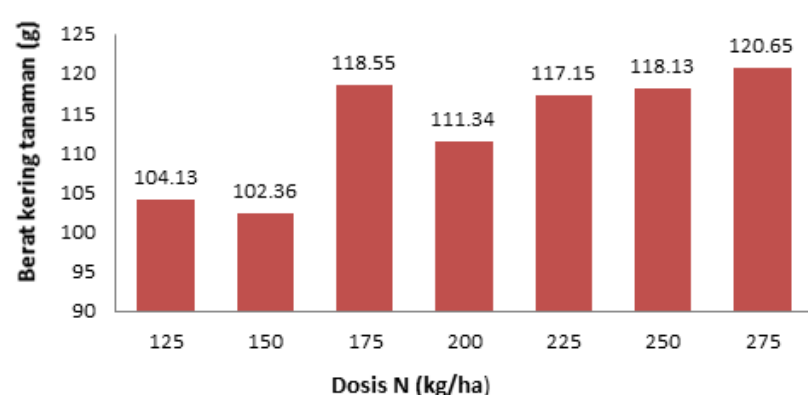

Gambar 2. Pengaruh Pemberian N Terhadap Berat Kering Tanaman

\section{Hasil Tanaman}

Komponen hasil ditentukan dengan beberapa parameter yaitu berat segar tongkol tanpa kelobot, berat kering tongkol tanpa kelobot, berat biji per tongkol, dan berat 100 biji pada kadar air
14\%. Penimbangan berat tongkol tanpa kelobot yang dipanen dari petak hasil pada saat jagung telah memasuki masak fisiologis dengan ditandai kelobot paling luar telah mengering dan lapisan pati sudah keras. Berat kering tongkol tanpa kelobot merupakan akumulasi dari hasil fotosintesis yang dilakukan oleh tanaman pada bagian tongkol dan biji setelah dihilangkan kelobotnya. Berat biji/tongkol pada kadar air 14\% diukur untuk menghitung hasil usaha tani yang didapatkan dari hasil jagung tersebut.

Tabel 2. Rerata Berat Segar Tongkol Tanpa Kelobot, Berat Kering Tongkol Tanpa Kelobot, Berat Biji/ Tongkol dan Berat 100 Biji Sebagai Respon terhadap Pemberian Dosis Nitrogen yang Berbeda

\begin{tabular}{lcccc}
\hline Perlakuan & $\begin{array}{c}\text { Berat Segar } \\
\text { Tongkol Tanpa } \\
\text { Kelobot (g) }\end{array}$ & $\begin{array}{c}\text { Berat Kering } \\
\text { Tongkol Tanpa } \\
\text { Kelobot (g) }\end{array}$ & $\begin{array}{c}\text { Berat Biji/ } \\
\text { Tongkol (g) }\end{array}$ & Berat 100 Biji \\
\hline $125 \mathrm{~kg} \mathrm{~N} / \mathrm{ha}$ & 167,80 & $130,75 \mathrm{a}$ & $9321 \mathrm{a}$ & 27,90 \\
$150 \mathrm{~kg} \mathrm{~N} / \mathrm{ha}$ & 124,80 & $93,95 \mathrm{ab}$ & $64,29 \mathrm{ab}$ & 24,40 \\
$175 \mathrm{~kg} \mathrm{~N} / \mathrm{ha}$ & 114,63 & $71,37 \mathrm{~b}$ & $51,42 \mathrm{~b}$ & 23,29 \\
$200 \mathrm{~kg} \mathrm{~N} / \mathrm{ha}$ & 113,17 & $80,57 \mathrm{~b}$ & $58,65 \mathrm{~b}$ & 23,46 \\
$225 \mathrm{~kg} \mathrm{~N} / \mathrm{ha}$ & 128,10 & $90,47 \mathrm{ab}$ & $69,34 \mathrm{ab}$ & 28,44 \\
$250 \mathrm{~kg} \mathrm{~N} / \mathrm{ha}$ & 134,40 & $95,60 \mathrm{ab}$ & $76,42 \mathrm{ab}$ & 26,10 \\
$275 \mathrm{~kg} \mathrm{~N} / \mathrm{ha}$ & 164,45 & $131,15 \mathrm{a}$ & $97,89 \mathrm{a}$ & 30,43 \\
\hline
\end{tabular}

Keterangan: Angka yang diikuti huruf yang sama dalam satu kolom menunjukkan tidak berbeda nyata berdasarkan DMRT $5 \%$.

Perlakuan dosis nitrogen memberikan pengaruh yang sama terhadap berat segar tongkol tanpa kelobot (Tabel 2). Hal ini disebabkan kebutuhan nitrogen pada fase generatif tidak sebanyak pada fase vegetatif sehingga penyerapan unsur nitrogen maksimal terjadi pada fase vegetatif dan mulai menurun pada saat memasuki fase generatif. Tanaman jagung pada fase vegetatif lebih membutuhkan nitrogen $(\mathrm{N})$, unsur tersebut dibutuhkan tanaman karena untuk pembentukan bagian vegetatifnya, terutama pada batang, akar dan daun. Sementara unsur nitrogen pada masa pertumbuhan generatifnya diperlukan untuk pembentukan tongkol (Lingga dan Marsono, 2000) dalam (Yuningsih, 2002). Hal ini 
diperkuat dengan pernyataan bahwa nitrogen merupakan unsur hara utama dalam penyediaan nutrisi tanaman, dan merupakan komponen utama dalam klorofil, protoplasma dan protein.

Nitrogen berperan dalam banyak proses fisiologi, terutama fase pertumbuhan vegetatif dan memberikan warna hijau daun. Namun demikian, terlalu banyak nitrogen dapat menghambat pembungaan dan pembuahan bahkan mengundang hama dan penyakit (Irmayani, 2011).

Pengamatan berat kering tongkol tanpa kelobot dilakukan setelah tongkol dijemur selama 2 hari. Pemberian pupuk N dengan dosis $125 \mathrm{~kg} /$ ha dan $275 \mathrm{~kg} /$ ha memberikan hasil bobot kering tongkol tanpa kelobot dan berat biji per tongkol yang paling tinggi (Tabel 2), walaupun hasil tersebut tidak berbeda nyata dengan perlakuan N 150 kg/ha, $225 \mathrm{~kg} / \mathrm{ha}, 250 \mathrm{~kg} / \mathrm{ha}$. Sementara pemberian pupuk $\mathrm{N}$ dengan dosis $175 \mathrm{~kg} / \mathrm{ha}$ dan $200 \mathrm{~kg} / \mathrm{ha}$ memberikan hasil berat kering tongkol tanpa kelobot dan berat biji per tongkol yang paling rendah. Pemberian unsur hara tanah bertujuan untuk menambah persediaan unsur hara yang dibutuhkan oleh tanaman, untuk meningkatkan produksi dan mutu hasil bagi tanaman (Sarief, 1986 dalam Yuningsih, 2002). Menurut Muhali (1977) dalam (Yuningsih, 2002) tujuan pemupukan selain untuk mengembalikan kesuburan tanah yang mengalami penurunan juga untuk mencapai produksi yang optimal.

Pola hubungan antara berat biji per tongkol pada kadar air 14\% dan dosis nitrogen dapat membentuk persamaan regresi kuadratik $Y=0,006831 x^{2}-2,652029 x+313,125714$ dengan nilai $\mathrm{R}^{2}=0,913$ yang berarti $91,3 \%$ berat biji/tongkol dipengaruhi oleh dosis nitrogen (Gambar 3). Sementara 8.7\% berat biji/tongkol dipengaruhi oleh faktor lain di luar perlakuan dosis nitrogen. Hal ini menunjukkan bahwa ketersediaan unsur hara $\mathrm{N}$ dalam tanah tercukupi untuk pembentukan buah. Respon tanaman sangat tergantung pada keseimbangan ketersediaan pupuk N,P,K bagi tanaman. Penyerapan nitrogen akan dipengaruhi oleh baik buruknya suplai unsur P dan K sebagaimana Anischan (2013) menyatakan bahwa tanpa pemberian $\mathrm{P}$ dan $\mathrm{K}$ respon hasil terhadap peningkatan $\mathrm{N}$ lebih rendah dibanding bila $\mathrm{P}$ dan $\mathrm{K}$ diberikan dalam jumlah yang cukup. Disamping itu, respon terhadap pemberian $\mathrm{P}$ dan $\mathrm{K}$ akan lebih besar bila suplai $\mathrm{N}$ makin banyak.

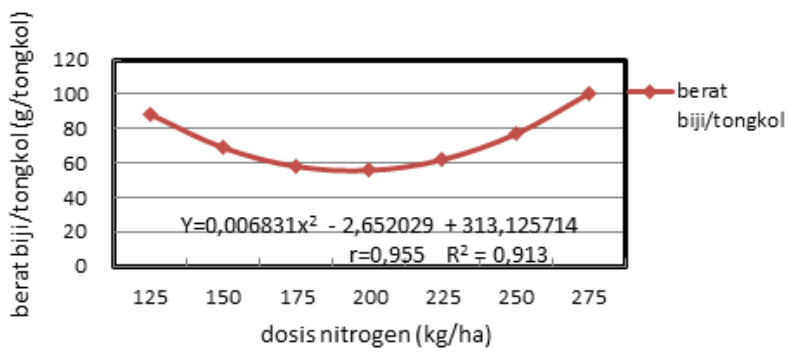

Gambar 3. Pengaruh Dosis N terhadap Berat Biji/ Tongkol Pada Kadar Air 14\%

Pemberian pupuk Nitrogen dengan berbagai dosis menunjukkan pengaruh yang tidak berbeda nyata terhadap berat 100 butir biji jagung. Hal ini menunjukkan bahwa semua perlakuan memberikan pengaruh yang sama terhadap parameter berat 100 butir biji yang artinya bahwa besar butir biji jagung dari tiap perlakuan juga tidak berbeda. Nitrogen adalah unsur hara utama dalam penyediaan nutrisi tanaman, dan merupakan komponen utama dalam klorofil, protoplasma dan protein. Nitrogen berperan dalam banyak proses fisiologi, terutama fase pertumbuhan vegetatif dan memberikan warna hijau daun (Irmayani, 2011).

Pola hubungan antara berat biji per tongkol pada kadar air 14\% dan dosis nitrogen dapat membentuk persamaan regresi kuadratik $Y=0,000812 x^{2}-0,301632 x+52,120857$ dengan nilai $\mathrm{R}^{2}=0,688$ yang artinya bahwa $68,8 \%$ berat 
100 butir biji dipengaruhi oleh dosis nitrogen (Gambar 4). Sementara 31,2\% berat 100 butir biji dipengaruhi oleh faktor lain di luar perlakuan dosis nitrogen. Hal ini menunjukkan bahwa pemberian nitrogen dalam jumlah yang cukup tersedia bagi tanaman maka akan memberikan hasil yang optimal karena pembentukan protein dalam tanaman untuk membentuk butiran buah juga maksimal. Sedikit N, P, dan $\mathrm{K}$ diserap tanaman pada pertumbuhan fase 2, dan serapan hara sangat cepat terjadi selama fase vegetatif dan pengisian biji. Unsur $\mathrm{N}$ dan $\mathrm{P}$ terus-menerus diserap tanaman sampai mendekati matang, sedangkan $\mathrm{K}$ terutama diperlukan saat silking. Sebagian besar N dan P dibawa ke titik tumbuh, batang, daun, dan bunga jantan, lalu dialihkan ke biji. Sebanyak 2/3-3/4 unsur $\mathrm{K}$ tertinggal di batang. Dengan demikian, $\mathrm{N}$ dan $\mathrm{P}$ terangkut dari tanah melalui biji saat panen, tetapi K tidak. Anischan (2013) menyatakan bahwa respon tanaman terhadap nitrogen juga tergantung pada baik buruknya suplai unsur hara lainnya. Tanpa pemberian $\mathrm{P}$ dan $\mathrm{K}$ respon hasil terhadap peningkatan $\mathrm{N}$ lebih rendah dibanding bila $\mathrm{P}$ dan $\mathrm{K}$ diberikan dalam jumlah yang cukup. Disamping itu, respon terhadap pemberian $\mathrm{P}$ dan $\mathrm{K}$ akan lebih besar bila suplai $\mathrm{N}$ makin banyak.

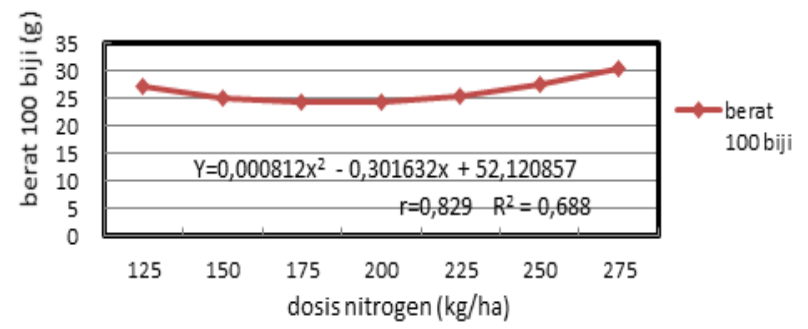

Gambar 4. Pengaruh Dosis N terhadap Berat 100 Butir Biji Jagung

Warna Daun

Pengamatan warna daun dilakukan pada saat tanaman memasuki fase vegetatif maksimal atau pada saat awal muncul bunga jantan yaitu sekitar umur 50-60 hari setelah tanam. Pengamatan warna daun dilakukan dengan menggunakan munshell color chart untuk mengetahui nilai klorofil pada tanaman. Hasil pengamatan warna daun jagung dan selanjutnya dikorelasikan dengan hasil berat biji/tongkol dan berat 100 butir biji jagung pada kadar 14\% maka, penetapan standar warna daun jagung untuk mendapatkan hasil jagung yang optimal yaitu pada skala antara 5GY 5/8 sampai 5GY 6/8 (Tabel 3).

\section{Tabel 3. Hasil Pengamatan Warna Hijau Daun}

\begin{tabular}{lc}
\hline Perlakuan & Skala Warna Daun \\
\hline $125 \mathrm{kgN} / \mathrm{ha}$ & $5 \mathrm{GY} 5 / 8$ \\
$150 \mathrm{kgN} / \mathrm{ha}$ & $5 \mathrm{GY} 5 / 8$ \\
$175 \mathrm{kgN} / \mathrm{ha}$ & $5 \mathrm{GY} 5 / 8$ \\
$200 \mathrm{kgN} / \mathrm{ha}$ & $5 \mathrm{GY} 6 / 10$ \\
$225 \mathrm{kgN} / \mathrm{ha}$ & $5 \mathrm{GY} 6 / 10$ \\
$250 \mathrm{kgN} / \mathrm{ha}$ & $5 G Y 5 / 8$ \\
$275 \mathrm{kgN} / \mathrm{ha}$ & $5 G Y 6 / 8$ \\
\hline
\end{tabular}

Hasil pengamatan warna daun dengan menggunakan munshell color chart menunjukkan adanya perbedaan tingkat kehijauan warna daun jagung dari berbagai perlakuan pupuk nitrogen (Tabel 3). Hal ini terjadi karena fungsi dari nitrogen yaitu selain merangsang pertumbuhan tanaman, juga memberikan warna hijau pada daun. Semakin gelap warna hijau daun pada tanaman jagung menunjukkan semakin tinggi unsur nitrogen yang diserap tanaman. Tingginya serapan unsur nitrogen oleh tanaman diharapkan akan meningkatkan berat kering tanaman dan juga hasil panen. Hal ini didukung dari pernyataan Soepardi (1983) bahwa pada serealia, nitrogen akan memperbesar butir-butir dan persentase protein.

Daun berfungsi sebagai organ utama fotosintesis pada tumbuhan tingkat tinggi. Permukaan luar daun yang luas dan datar memungkinkan- 
nya menangkap cahaya semaksimal mungkin per satuan volume dan meminimalkan jarak yang harus ditempuh oleh $\mathrm{CO}_{2}$ dari permukaan daun ke kloroplas, yaitu jarak sekitar 0,1 mm pada daun-daun kebanyakan tanaman budidaya (Gardner, dkk., 1991). Soepardi (1983) menyatakan dari tiga unsur yang biasanya diberikan sebagai pupuk, nitrogen merupakan yang paling menyolok dan cepat. Nitrogen berperan merangsang pertumbuhan di atas tanah dan memberikan warna hijau pada daun. Pada serealia nitrogen akan memperbesar butir-butir dan persentase protein.

Buckman dan Brady (1982) menyatakan bahwa nitrogen cenderung menghasilkan sukulen yaitu kualitas khusus yang diharapkan pada tanaman tertentu seperti selada dan lobak (sayuran). Tanaman yang kekurangan nitrogen akan tumbuh kerdil dan memiliki sistem perakaran terbatas. Daun menjadi kuning atau hijau kekuningan dan cenderung mudah jatuh.

Gardner, dkk. (1991) menyatakan bahwa agar pemanfaatan radiasi matahari oleh tanaman budidaya dapat dilakukan secara efisien, maka penyerapan radiasi tersebut harus sebagian oleh jaringan fotosintesisnya yang hijau. Untuk mendapatkan warna hijau yang tepat pada daun jagung maka pemberian nitrogen menjadi cara yang efektif. Fotosintesis menjadi satu-satunya sumber energi bagi kehidupan tanaman selama pertumbuhan. Kandungan klorofil yang ada di dalam daun menunjukkan status hara $\mathrm{N}$ pada tanaman.

\section{SIMPULAN}

1. Skala warna daun yang tepat untuk mengidentifikasi status hara $\mathrm{N}$ pada hasil tanaman jagung yaitu antara skala 5GY 5/8 - 5GY 6/8 pada dosis antara $250 \mathrm{~kg} / \mathrm{ha}$ sampai $275 \mathrm{~kg} /$ ha.
2. Pemberian pupuk nitrogen dengan dosis 250 $\mathrm{kg} / \mathrm{ha}$ memberikan pengaruh pertumbuhan paling tinggi pada parameter tinggi tanaman. 3).

3. Pemberian pupuk nitrogen dengan dosis 275 $\mathrm{kg} / \mathrm{ha}$ memberikan hasil paling tinggi pada komponen berat biji/tongkol dan berat 100 butir biji pada kadar air 14\%.

\section{DAFTAR PUSTAKA}

Adinata, K. 2004. Pertumbuhan vegetative tanaman jagung (Zea may L.) yang diberi kombinasi zeolite dan pupuk nitrogen di lahan pasir pantai. Yogyakarta. $62 \mathrm{~h}$

Anischan, G. 2013. Bagan Warna Daun (BWD). Balai Besar Penelitian Tanaman Padi

Balai Penelitian Tanah. 2008. Perangkat Uji Tanah Kering. Warta. Penelitian dan Pengembangan Pertanian. Vol. 30, No. 5. h.13

Buckman, H.O., dan N. C. Brady. 1989. IImu Tanah. Diterjemahkan oleh Soegiman. Barata Karya Aksara. Jakarta. $721 \mathrm{~h}$

Djaafar TF, Sarjiman, Pustika AB. 2010. Pengembangan Budi Daya Tanaman Garut dan Teknologi Pengolahannya Untuk Mendukung Ketahanan Pangan. J Litbang Pertanian 29 (1): 25-33

Gardner, F.P, Pearce, R.B dan Mitchell, R.L. 1991. Fisiologi Tanaman Budidaya. Ul press. Jakarta. $428 \mathrm{~h}$

Irmayani, T. 2011. Pengaruh Pemberian Pupuk Nitrogen Terhadap Timbulnya Penyakit Daun Tanaman Jagung (Zea Mays L.) Pada Beberapa Varietas Di Lapangan. http://repository.usu.ac.id/ handle/123456789/23043. Diakses pada 13 Mei 2013

Lingga, P dan Marsono, 2000. Petunjuk Penggunaan Pupuk. Penebar Swadaya. Jakarta.

Nurhayati, S. 2003. Pengaruh Dosis Dan Saat Pemberian Pupuk NPK Terhadap Hasil Jagung Hibrida (Zea mays L.). Yogyakarta. 58h. Skripsi fakultas Pertanian Universitas Muhammadiyah Yogyakarta

Soepardi,G. 1988. Sifat dan Ciri Tanah. Departemen Institut Pertanian Bogor. 591p Dalam Skripsi Sri, Y. 2002. Kajian dosis dan frekuensi pupuk nitrogen pada pertumbuhan dan hasil jagung (Zea mays L.). Yogyakarta. 57h

Suwardi dan R. Efendi. 2009. Efisiensi Penggunaan Pupuk N Pada Jagung Komposit Menggunakan Bagan Warna Daun. ., Diakses 15 Mei 2013

Utami, S. 2005. Pengaruh Sistem Olah Tanah Terhadap Pertumbuhan Dan Hasil Jagung Manis (Zea mays Saccharata Strurt). Yogyakarta. 61h Skripsi Fakultas Pertanian Universitas Muhammadiyah Yogyakarta

Wahid, A.S., 2003. Peningkatan Efisiensi Pupuk Nitrogen Pada Padi Sawah Dengan Metode Bagan Warna Daun. Jurnal Libang Pertanian. H. 157.

Yuningsih, S. 2002. Kajian dosis dan frekuensi pupuk nitrogen pada pertumbuhan dan hasil jagung (Zea mays L.). Yogyakarta. 57h. Skripsi Fakultas Pertanian Universitas Muhammadiyah Yogyakarta 